\title{
HUBUNGAN PENGGUNAAN MEDIA SOSIAL INFO COMMUTER LINE PT KAI DAN SIKAP PENUMPANG DI STASIUN BOJONG GEDE TERHADAP KEPUASAN PELAYANAN PERJALANAN KERETA COMMUTER LINE JABODETABEK
}

\author{
${ }^{1}$ Siap Bangun Negara, ${ }^{2}$ Mulharnetti Syas \\ ${ }^{1,2}$ Institut Ilmu Sosial dan Ilmu Politik Jakarta \\ Email: siaptopskor@gmail.com
}

\begin{abstract}
Abstrak
Permasalahan kemacetan lalu lintas merupakan masalah besar yang dihadapi oleh sebagian penduduk Indonesia, terutama bagi mereka yang tinggal di Ibu kota Jakarta dan kota-kota yang berbatasan langsung dengan Jakarta seperti: Tangerang, Bogor, Depok, dan Bekasi. Kereta api terutama PT KCJ merupakan alternatif untuk masalah angkutan jalan raya bagi Masyarakat. Tujuan penelitian ini adalah menganalisis hubungan antara penggunaan media sosial Twitter Info Commuter line PT KAI Indonesia dan sikap penumpang di Stasiun Bojong Gede terhadap kepuasan pelayanan perjalanan kereta commuter line Jabodetabek. Pengambilan sampel dengan teknik simple random sampling, yaitu hanya penumpang kereta commuter line yang memperoleh informasi jadwal dan pelayanan kereta commuter line dari media sosial Twitter Info Commuter Line. Metode penelitian dalam penelitian ini adalah pendekatan kuantitatif. Hasil penelitian ini menunjukkan bahwa penggunaan media sosial berpengaruh positif dan signifikan terhadap kepuasan pelayanan, dan sikap penumpang.
\end{abstract}

Kata Kunci: kepuasan pelayanan, kereta commuter line jabodetabek, penggunaan media, pt kai. sikap penumpang, twitter

\begin{abstract}
The problem of traffic congestion is a big problem faced by some of Indonesia's population, especially for those who live in Jakarta Capital City and cities that directly borders with Jakarta such as Tangerang, Bogor, Depok, and Bekasi. Trains, especially PT KCJ, are an alternative to the problem of highway transportation for the Community. The purpose of this study is to analyze the relationship between the use of social media Twitter Info Commuter line PT KAI Indonesia and the attitude of passengers in Bojong Gede Station to the satisfaction of the Jabodetabek commuter line train service. Sampling with simple random sampling technique, which is only commuter line train passengers who obtain schedule information and commuter line train service from social media Twitter Info Commuter Line. Research method in this research is quantitative approach. The results of this study indicate that the use of social media has a positive and significant impact on service satisfaction, and passenger attitude.
\end{abstract}

Keywords: commuter line train jabodetabek, media usage, passenger attitude, pt kai, service satisfaction, twitter

\section{PENDAHULUAN}

Permasalahan kemacetan lalu lintas merupakan masalah besar yang dihadapi oleh sebagian penduduk Indonesia, terutama bagi mereka yang tinggal di ibu kota Jakarta dan kota-kota yang berbatasan langsung dengan Jakarta seperti: Tangerang, Bogor, Depok, dan Bekasi. Pertumbuhan jumlah penduduk yang cepat mendorong berkembangnya kuantitas alat transportasi baik transportasi pribadi seperti kendaraan roda dua (sepeda motor), kendaraan 
roda empat (mobil) ataupun transportasi publik seperti bus, taksi, angkutan kota (angkot), dan kereta.

PT KAI Commuter Jabodetabek adalah salah satu anak perusahaan di lingkungan PT Kereta Api Indonesia (Persero) yang mengelola KA Commuter Jabodetabek (KCJ). Kereta api terutama PT KCJ merupakan alternatif bagi masalah angkutan jalan raya bagi masyarakat. Sejalan misi kereta api, lebih menekankan akan kualitas produk atau jasa yang diberikan oleh perusahaan sesuai dengan keinginan konsumen. Hal ini disebabkan kualitas jasa sangat tergantung dari siapa dan bagaimana jasa itu diberikan.

Layanan pelanggan (customer service) merupakan bagian yang sangat penting dalam strategi bisnis. Layanan pelanggan memainkan peran strategis dalam meminimalkan masalah terkait dengan pelanggan. Layanan pelanggan merupakan aktivitas untuk meningkatkan tingkat kepuasan pelanggan sebelum, selama, atau setelah pembelian. Layanan pelanggan mengacu pada setiap layanan yang diberikan perusahaan kepada pelanggan untuk memenuhi kebutuhan mereka dan menjaga pelanggan tetap melekat pada perusahaan (Faed, et al., 2014).

Salah satu bentuk layanan pelanggan yang di berikan PT KAI Commuter Jabodetabek adalah penggunaan Media Sosial Twitter Info Commuter Line. Sosial media memberikan kemudahan dalam berkomunikasi dan memiliki kemampuan untuk menyajikan komunikasi dua arah (Treem, et al., 2013). Hal tersebut memudahkan perusahaan untuk berinteraksi dengan pelanggan. Melalui sosial media perusahaan dapat berbagi informasi penting dengan pelanggan, menjaga hubungan baik dengan pelanggan, dan mendapatkan feedback dengan cara yang sangat mudah dan cepat.

Kepuasan terhadap jasa transportasi KRL merupakan keseluruhan konstruksi yang dipengaruhi oleh ekspektasi penumpang dan persepsi kinerja pada periode tertentu, dan juga dipengaruhi oleh kepuasan masa lalu dari periode ke periode (Cronin et al., 2000). Dari definisi ini, kepuasan pelanggan terletak pada diskonfirmasi paradigma harapan pelanggan, sedangkan diskonfirmasi positif menyebabkan kepuasan pelanggan dan negatif kepuasan menyebabkan ketidakpuasan pelanggan (Lam et al., 2004). Kepuasan pelanggan ditentukan oleh persepsi pelanggan atas kinerja produk atau jasa dalam memenuhi harapan. Pelanggan merasa puas apabila harapannya terpenuhi atau akan sangat puas jika harapan pelanggan terlampaui, ada lima faktor utama pelanggan yaitu kualitas produk, harga, kualitas layanan, faktor emosional, biaya, dan kemudahan (Hidayat, 2009).

Sikap positif konsumen terhadap suatu layanan maka akan menjadikan konsumen memilih layanan tersebut. Begitu pula sebaliknya, jika suatu layanan telah disikapi negatif oleh konsumen maka layanan tersebut tidak akan menjadi pilihan konsumen. layanan yang dalam penelitian ini tercakup dalam merek lokal dan asing memiliki ciri masing-masing yang dapat membawa keunggulan dalam bersaing memperebutkan pilihan konsumen.

Lebih lanjut komunikasi negatif dapat mempengaruhi sikap dan niat membeli dari pelanggan dan berpotensi merusak citra perusahaan (Balaji, Khong, \& Chong, 2016). Secara khusus perasaan ketidakadilan dan atribut perusahaan memengaruhi pelanggan mengirimkan komunikasi negatif di media sosial. Hal lain yang perlu diperhatikan adalah kemungkinan pesaing mengekploitasi komunikasi negatif untuk merusak reputasi perusahaan. 
Berdasarkan latar belakang dan penjelasan yang diuraikan diatas, dalam kesempatan ini penelitian yang dilakukan berjudul: "Hubungan penggunaan media sosial Twitter Info Commuter Line PT KAI Indonesia, dan sikap penumpang di Stasiun Bojong Gede terhadap kepuasan pelayanan perjalanan kereta commuter line Jabodetabek pada April 2018.”

Ada pun tujuan penelitian ini. Pertama, menganalisis penggunaan media sosial Twitter Info Commuter Line PT KAI Indonesia oleh penumpang di Stasiun Bojong Gede. Kedua, menganalisis kepuasan penumpang di Stasiun Bojong Gede akan informasi jadwal dan pelayanan kereta commuter line yang diperoleh dari media sosial Twitter Info Commuter Line. Ketiga, menganalisis sikap penumpang di Stasiun Bojong Gede terhadap pelayanan perjalanan kereta commuter line Jabodetabek sehari-hari. Empat, Menganalisis hubungan antara penggunaan media sosial Twitter Info Commuter Line PT KAI Indonesia dengan kepuasan penumpang di Stasiun Bojong Gede. Kelima, menganalisis hubungan antara penggunaan media sosial Twitter Info Commuter Line PT KAI Indonesia dan sikap penumpang di Stasiun Bojong Gede terhadap kepuasan pelayanan perjalanan kereta commuter line Jabodetabek sehari-hari.

Penelitian ini mengambil perspektif paradigma positivis. Asumsi dasar paradigma positivis terdeskripsikan dalam uraian Sarantakos (Grant, B. M., \& Giddings, L. S. 2002) dalam berbagai persepsi paradigma dalam memandang suatu realitas sosial, keberadaan manusia (human being), ilmu pengetahuan (nature of science) dan tujuan penelitian sosial.

Pertama, persepsi paradigma positivis dalam memandang realitas adalah bahwa realita sebagai "out there", bebas dari kesadaran manusia, obyektif, patuh pada keteraturan (rest on order), diatur oleh hukum yang ketat, alamiah dan tidak berubah, bisa direalisasikan melalui pengalaman. Cara pandang masyarakat adalah sama karena mereka saling berbagi arti yang sama pula.

\section{Kualitas Pelayanan Publik}

Berdasarkan cara pandang masyarakat akan terlihat bagaimana kualitas pelayanan publik, dalam penelitian ini tentunya bagaimana kualitas pelayanan transportasi kereta Commuter Line PT KAI dalam melayani penumpangnya (publik). Transportasi menurut Adisasmita (2011:1) dirumuskan sebagai kegiatan memindahkan atau mengangkat muatan (barang dan manusia) dari suatu tempat ke tempat lain, dari suatu tempat asal (origin) ke tempat tujuan (destination). Nantinya, kualitas pelayanan itulah yang akan dinilai oleh penumpang dan mereka suarakan melalui akun media sosial Twitter masing-masing lalu kemudian disalurkan ke akun media sosial Twitter Info Commuter Line PT KAI.

Kualitas pelayanan pada prinsipnya berfokus pada upaya pemenuhan kebutuhan dan keinginan pelanggan serta ketepatan penyampaian untuk mengimbangi harapan pelanggan (Tjiptono, 2009:246). Kualitas layanan sendiri bisa diartikan sebagai ukuran seberapa bagus tingkat layanan yang diberikan mampu sesuai dengan ekspektasi pelanggan (Lewis \& Booms dalam Tjiptono, 2012:157).

Sedangkan pelayanan publik disimpulkan sebagai pemberian jasa baik oleh pemerintah, pihak swasta atas nama pemerintah ataupun pihak swasta kepada masyarakat, dengan atau tanpa pembayaran guna memenuhi kebutuhan dan/atau kepentingan masyarakat (Wasistiono, 2001:51-52). 
Ditambahkan Tjiptono (dalam Hardiyansyah, 2011:40), dalam menentukan kualitas pelayanan publik diperlukan ciri-ciri atau atribut-atribut, antara lain: (1) Ketepatan waktu pelayanan; Akurasi pelayanan; (3) Kesopanan dan keramahan; (4) Kemudahan dalam mendapatkan pelayanan; (5) Kenyamanan dalam memperoleh pelayanan; (6) Atribut pendukung pelayanan lainnya.

Zulkifli dan Syahputra (2016:2007) dalam penelitiannya menganalisis faktor-faktor yang mempengaruhi kualitas pelayanan Commuter Line PT KAI gerbong khusus wanita. Dua faktor menjadi paling dominan mempengaruhi kualitas pelayanan Commuter Line PT KAI gerbong khusus wanita, yaitu Service Delivery and Credibility. Layanan prima selalu diberikan bagi penumpang Commuter Line PT KAI gerbong khusus wanita. Disimpulkan juga bahwa pengelola (PT KAI) dapat diandalkan, tepat dalam mengelola waktu kedatangan kereta, lalu apabila ada penumpang wanita yang memerlukan bantuan petugas langsung menghampiri, kemudian lampu di dalam gerbong berfungsi dengan baik dan tiket yang mudah didapat.

Sementara penelitian Jayanti dan Hardjo (2012) menggambarkan kualitas pelayanan Commuter Line PT KAI rute Jakarta-Bogor berdasarkan persepsi mahasiswa Universitas Indonesia. Dalam mengukur kualitas pelayanan Commuter Line PT KAI rute Jakarta-Bogor berdasarkan teori kualitas jasa menurut Brady dan Cronin (2001) didukung oleh tiga dimensi yaitu dimensi kualitas interaksi, dimensi kualitas lingkungan fisik dan dimensi kualitas hasil. Berdasarkan hasil penelitian, diketahui bahwa kualitas pelayanan Commuter Line PT KAI rute Jakarta-Bogor berdasarkan persepsi mahasiswa Universitas Indonesia dinilai baik.

Kedua penelitian tersebut (Zulkifli dan Syahputra, Jayanti dan Hardjo) menjadi dasar dari penelitian ini namun dengan meneliti kualitas pelayanan publik yang disalurkan (diunggah) ke media sosial Twitter Info Commuter Line PT KAI.

\section{Teori Uses and Gratification}

Teori Uses and Gratification adalah perluasan dari teori kebutuhan dan motivasi (Kania, D., \& Agatha, N. 2012). Dalam teori kebutuhan dan motivasi, Abraham Maslow menyatakan bahwa orang secara aktif berusaha untuk memenuhi hirearki kebutuhannya. Setelah mereka memperoleh tujuan yang mereka cari pada satu tingkat hirearki, mereka dapat bergerak ke tahap berikutnya. Gambaran mengenai manusia sebagai seseorang yang aktif, berusaha untuk memuaskan kebutuhannya, sesuai dengan ide yang dibawa Katz, Blumler, dan Gurevitch ke dalam kajian mereka mengenai bagaimana manusia mengkonsumsi komunikasi massa (West \& Turner, 2007:101).

Menurut Dhaha, I. S. Y., \& Igale, A. B. (2013) teori Uses and Gratifications lebih menekankan pada pendekatan manusiawi. Artinya, manusia itu memiliki otonomi dan wewenang dalam memberlakukan media. Karena khalayak mempunyai banyak alasan untuk menggunakan media. Selain itu, konsumen mempunyai kebebasan untuk memutuskan bagaimana mereka menggunakan media dan bagaimana media itu berdampak untuk dirinya. Karena menurut teori ini mungkin saja media dapat mempunyai pengaruh jahat dalam kehidupan mereka.

Terdapat 5 asumsi dasar teori yaitu khalayak aktif; Inisiatif dalam pemilihan media; Media berkompetisi dengan sumber lainnya; Audiens mempunyai kesadaran diri akan 
penggunaan media; Kepuasaan yang diperoleh dapat berasal dari isi media, terpaan media dan situasi sosial dimana terpaan media terjadi.

Kazt dan Blumler (Baran, S. J., \& Davis, D. K. 2011) mengemukakan ada beberapa faktor sosial yang menyebabkan timbulnya kebutuhan seseorang yang berhubungan dengan media, yaitu: Situasi sosial menimbulkan ketegangan dan pertentangan. Orang berusaha melepaskan dirinya dari hal itu dengan mengkonsumsi media massa; Situasi sosial menciptakan kesadaran akan adanya masalah yang membutuhkan perhatian dan informasi. Informasi itu dapat dicari lewat media; dan Situasi sosial memberikan dukungan dan penguatan pada nilai-nilai tertentu melalui konsumsi media yang selaras.

Media massa saat ini menjadi salah satu alat penyebarluasan informasi secara cepat dan global, karena sesuai dengan fungsinya yaitu menyampaikan informasi, mendidik, menghibur, mempengaruhi, serta mengontrol masyarakat dan pemerintah. Penggunaan media sosial sebagai alat bisnis perusahaan menawarkan beberapa keuntungan bagi perusahaan (Seol, Lee, Yu, \& Zo, 2016). Diantaranya membantu perusahaan meningkatkan citra perusahaan dengan mengelola hubungan yang baik dengan pelanggan, sehingga meningkatkan penjualan dan mengurangi biaya untuk mempertahankan pelanggan. Keuntungan lain, perusahaan dapat dengan mudah berinteraksi dengan pelanggan melalui media sosial dan dapat membangun kepercayaan untuk berbagi layanan dengan pelanggan. Memiliki hubungan yang baik dengan pelanggan sangat membantu bagi perusahaan dalam banyak hal.

Terpaan media berbicara mengenai khalayak dalam penggunaan media, baik jenis media, frekuensi penggunaan (frequency), maupun durasi penggunaan (longevity). Penggunaan jenis media meliputi media audio, audiovisual, media cetak, ataupun kombinasi beberapa media (Ardianto \& Komala, 2005:168).

\section{Sikap}

Suatu sikap, menurut Shader, M. (2001) adalah organisasi yang bertahan lama dari proses motivasi, emosional, perseptual, dan kognitif sehubungan dengan beberapa aspek lingkungan kita. Ini berarti bahwa sikap dikembangkan dari rangsangan lingkungan, seperti produk yang ditawarkan kepada konsumen dan bagaimana mereka dikomunikasikan.

Myers, R. E., \& Fouts, J. T. (1992) mengatakan bahwa sikap adalah a predisposition towards some object; includes one's beliefs, feelings, and behavior tendencies concerning the object. Dari pendapat Myers tersebut maka diketahui bahwa dalam sikap meliputi tiga komponen, yaitu:

1. Komponen kognitif.

2. Komponen afektif.

3. Komponen konatif.

Sikap memimpin orang untuk berperilaku dengan cara yang cukup konsisten terhadap objek yang serupa. Boone dan Kurtz (2004) mendeskripsikan sikap sebagai seseorang yang bertahan baik evaluasi yang menguntungkan atau tidak menyenangkan, emosi atau kecenderungan tindakan terhadap beberapa objek atau data. Ketika mereka terbentuk dari waktu ke waktu melalui pengalaman individu dan sikap kontak kelompok menjadi sangat tahan terhadap perubahan. Foster-Fishmanet al (2001) mempertahankan 
bahwa sikap dibentuk oleh nilai-nilai dan keyakinan kita, yang dipelajari. Nilai bervariasi menurut tingkat kekhususan. Schwartz, S. H. (2012) mendeskripsikan nilai sebagai keyakinan bersama atau norma budaya tentang apa yang penting atau benar. Nilai-nilai, seperti kebutuhan untuk menjadi milik atau untuk berhasil, mewakili tujuan-tujuan penting yang menjadi langganan konsumen. Nilai ditransmisikan ke individu melalui lingkungan langsung dan terpencil seperti keluarga, organisasi (sekolah, agama, lembaga, bisnis), dan orang lain (masyarakat, lingkungan sosial). Dawar, N., \& Parker, P. (1994) mengamati bahwa nilai budaya secara langsung mempengaruhi bagaimana konsumen melihat dan menggunakan produk, merek, dan layanan individual. Nilai mempengaruhi tujuan yang orang kejar dan perilaku yang digunakan untuk mengejar tujuan tersebut. Banyak kampanye komunikasi pemasaran mengakui pentingnya nilai sebagai tema iklan dan justifikasi untuk pembelian.

\section{Kepuasan}

Kepuasan terhadap jasa transportasi KRL merupakan keseluruhan konstruksi yang dipengaruhi oleh ekspektasi penumpang dan persepsi kinerja pada periode tertentu, dan juga dipengaruhi oleh kepuasan masa lalu dari periode ke periode (Cronin et al., 2000). Dari definisi ini, kepuasan pelanggan terletak pada diskonfirmasi paradigma harapan pelanggan, sedangkan diskonfirmasi positif menyebabkan kepuasan pelanggan dan negatif kepuasan menyebabkan ketidakpuasan pelanggan. Kepuasan pelanggan ditentukan oleh persepsi pelanggan atas kinerja produk atau jasa dalam memenuhi harapan. Pelanggan merasa puas apabila harapannya terpenuhi atau akan sangat puas jika harapan pelanggan terlampaui, ada lima faktor utama pelanggan yaitu kualitas produk, harga, kualitas layanan, faktor emosional, biaya, dan kemudahan.

\section{Kerangka pemikiran}

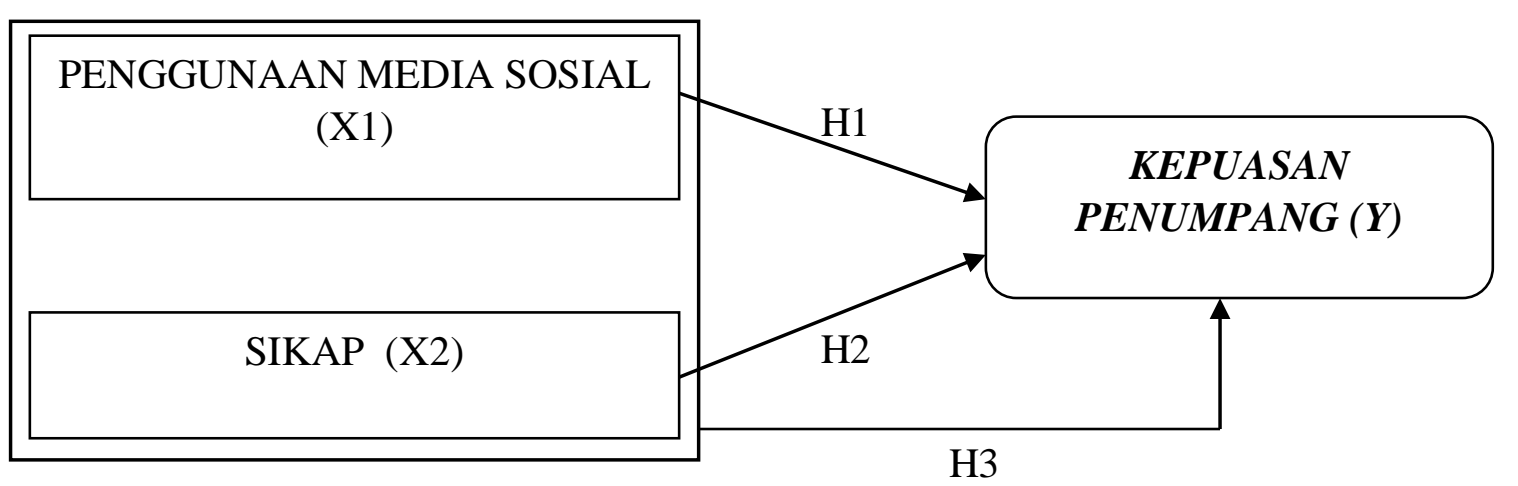

\section{Hipotesis}

Setelah peneliti mengadakan penelaahan yang mendalam terhadap berbagai sumber untuk menentukan anggapan dasar, maka langkah berikutnya adalah merumuskan hipotesis.

Berdasarkan hasil uraian pada kajian pustaka yang ada serta konsep kerangka berpikir, maka rumusan hipotesis yang dapat dikemukakan untuk penelitian ini adalah sebagai berikut : 
$\mathrm{H} 1=$ Penggunaan media sosial berpengaruh terhadap kepuasan penumpang.

$\mathrm{H} 2=$ Sikap berpengaruh terhadap kepuasan penumpang

H3 = Penggunaan media sosial dan sikap secara simultan berpengaruh terhadap kepuasan penumpang

\section{METODOLOGI PENELITIAN}

Pendekatan dalam penelitian ini adalah pendekatan kuantitatif, karena penelitian ini disajikan dengan angka-angka. Hal ini sesuai dengan pendapat (Arikunto 2006:12) yang mengemukakan penelitian kuantitatif adalah pendekatan penelitian yang banyak dituntut menggunakan angka, mulai dari pengumpulan data, penafsiran terhadap data tersebut, serta penampilan hasilnya.

\section{Populasi dan Sampling}

Populasi dalam penelitian ini menggunakan simple random sampling. Populasi dan sampling: 50 orang penumpang kereta commuter line yang berangkat dan tujuan akhirnya dari Stasiun Kereta Bojong Gede, Kabupaten Bogor. Waktu penelitian dilaksanakan: selama bulan April 2018 atau 1-30 April 2018. Pengambilan sampel dengan teknik simple random sampling, yaitu hanya penumpang kereta commuter line yang memperoleh informasi jadwal dan pelayanan kereta commuter line dari media sosial Twitter Info Commuter Line.

\section{Pengukuran Variabel}

Skala pengukuran yang digunakan oleh peneliti untuk menyatakan tanggapan dari responden terhadap setiap pertanyaan yang diberikan adalah dengan menggunakan Skala Likert. Menurut Sugiyono (2004) Skala Likert digunakan untuk mengukur sikap, pendapat, dan persepsi seseorang atau sekelompok orang tentang fenomenasosial.

Dalam penelitian fenomenasosial ini telah ditetapkan secara spesifik oleh peneliti yang selanjutnya disebut sebagai variabel penelitian, dengan Skala Likert, maka variabel yang akan diukur dijabarkan menjadi indikator variabel. Kemudian indikator tersebut dijadikan sebagai titik tolak untuk menyusun item-item instrumen yang dapat berupa pernyataan atau pertanyaan.

Jawaban setiap item instrumen yang menggunakan Skala Likert mempunyai gradasi dari sangat positif sampai negatif yang dapat berupa kata-kata antara lain: Sangat setuju (SS) : Skor 5; Setuju(S) : Skor 4; Netral (N) : Skor 3; Tidak setuju (TS) : Skor 2; Sangat tidak setuju (STS) : Skor 1

Teknik pengumpulan data penelitian dalam penelitian ini diantaranya yaitu menggunakan wawancara. Menurut Sugiyono (2012) wawancara digunakan sebagai teknik pengumpulan data apabila peneliti ingin melakukan studi pendahuluan untuk menemukan masalah yang harus diteliti dan juga apabila peneliti ingin mengetahui hal-hal dari responden yang lebih mendalam dan jumlah respondennya sedikit/kecil. Wawancara dapat dilakukan secara terstruktur (peneliti telah mengetahui dengan pasti tentang informasi apa yang akan diperoleh) maupun tidak terstruktur (peneliti tidak menggunakan pedoman wawancara yang telah tersusun secara sistematis dan lengkap sebagai pengumpul datanya) dan dapat 
dilakukan secara langsung (tatap muka) maupun secara tidak langsung (melalui media seperti telepon).

Teknik yang utama digunakan adalah kuesioner. Kuesioner adalah sejumlah pertanyaan tertulis yang digunakan untuk memperoleh informasi dari responden dalam arti laporan tentang pribadinya, atau hal-hal yang ia ketahui (Arikunto, 2002). Kelebihan menggunakan kuesioner adalah dalam waktu yang relatif singkat dapat memperoleh data yang banyak, tenaga yang diperlukan sedikit dan responden dapat menjawab dengan bebas tanpa pengaruh orang lain. Sedangkan kelemahan kuesioner adalah angket bersifat kaku karena pertanyaan yang telah ditentukan dan responden tidak memberi jawaban yang sesuai dengan keadaan dirinya hanya sekedar membaca kemudian menulis jawabannya.

Selain itu, penelitian ini juga menggunakan teknik dokumeentasi. Dokumen adalah segala benda yang berbentuk barang, gambar, ataupun tulisan sebagi bukti dan dapat memberikan keterangan yang penting dan absah. Dokumentasi adalah kumpulan dari dokumen-dokumen yang dapat memberikan keterangan atau bukti yang berkaitan dengan proses pengumpulan dan pengelolaan dokumen secara sistematis serta menyebarluaskan kepada pemakai informasi tersebut. Peneliti memperoleh data dan dokumen-dokumen tertulis. Penulis membaca dan mempelajari berbagai tulisan dari buku-buku, jurnal-jurnal, dan internet yang berkaitan dan mendukung kebenaran dan keabsahan dari hasil yang diperoleh dari penelitian ini.

\section{HASIL DAN PEMBAHASAN}

Analisis regresi berganda digunakan untuk meramalkan bagaimana fluktuasi variabel dependen melalui dua atau lebih variabel independen. Dalam penelitian ini ada dua varabel independen yang akan digunakan yaitu penggunaan media sosial Twitter dan sikap penumpang di Stasiun Bojong Gede, sedangkan yang menjadi variabel dependennya adalah kepuasan pelayanan perjalanan kereta commuter line Jabodetabek.

Hasil analisis regresi linier berganda antara hubungan penggunaan media sosial Twitter Info Commuter Line PT KAI Indonesia, dan sikap penumpang di Stasiun Bojong Gede terhadap kepuasan pelayanan perjalanan kereta commuter line Jabodetabek adalah sebagai berikut:

Tabel 1. Hasil Regresi penggunaan media dan sikap Terhadap kepuasan pelayanan

Coefficients $^{\mathrm{a}}$

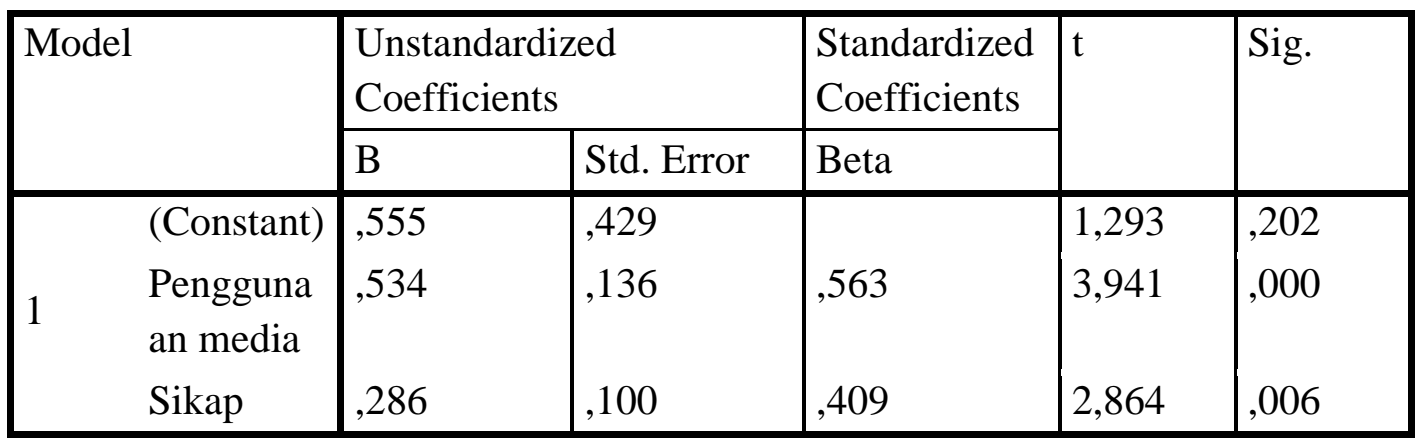


Dari hasil perhitungan SPSS di atas dapat diperoleh rumusan persamaan regresi linier berganda untuk variabel independen (Penggunaan media, dan Sikap) terhadap variabel dependen (kepuasan pelayanan) sebagai berikut:

$$
\hat{\mathrm{Y}}=0.555+0.534 \mathrm{X}_{1}+0.286 \mathrm{X}_{2}+\mathrm{e}
$$

Hasil perhitungan analisis mengidentikasikan bahwa nilai a (konstanta) sebesar 0.555 berarti jika tidak ada variabel independen penggunaan media, dan Sikap, maka kepuasan pelayanan akan sebesar 0.555 .

Nilai $b_{1}$ (koefisien Penggunaan media) sebesar 0.534 menunjukkan adanya pengaruh positif atau penerimaan Penggunaan media terhadap kepuasan pelayanan, berarti bahwa tiap kenaikan sebesar satu satuan pada Penggunaan media akan meningkatkan kepuasan pelayanan sebesar 0.534 dengan asumsi Sikap tetap.

Nilai $b_{2}$ (koefisien Sikap) sebesar 0.286 menunjukkan adanya pengaruh positif atau penerimaan Sikap terhadap kepuasan pelayanan, berarti bahwa tiap kenaikan sebesar satu satuan pada Sikap akan meningkatkan kepuasan pelayanan sebesar 1.768 dengan asumsi Penggunaan media tetap.

\section{Uji Hipotesis dan Analisis}

\section{Hipotesis penelitian pertama menyatakan bahwa:}

Hasil uji t dapat dilihat pada tabel 1 dari hasil regresi linier sederhana dengan penjelasan sebagai sebagai berikut:

$\mathrm{H}_{1}$ : Terdapat pengaruh penggunaan media terhadap kepuasan pelayanan.

Berdasarkan hasil analisis regresi linier sederhana, variabel penggunaan media diperoleh koefisien regresi sebesar 0.534 dan nilai $t_{\text {hitung }}=3,941$ dengan tingkat signifikansi 0.000

Dengan menggunakan batas signifikansi 0.05, didapat $\mathrm{t}_{\text {tabel }}$ sebesar 1.677. Ini berarti $\mathrm{t}$ hitung lebih besar dari $\mathrm{t}_{\text {tabel}}$, yaitu 3,941 lebih besar dari 1.677, berarti Ho ditolak dan Ha diterima. Dengan demikian maka hipotesis penelitian pertama $\left(\mathbf{H}_{1}\right)$ dapat diterima atau terbukti. Arah koefisien regresi positif berarti bahwa penggunaan media memiliki pengaruh positif yang signifikan terhadap kepuasan pelayanan. Dengan kata lain dapat disimpulkan bahwa penggunaan media penting dan berpengaruh dalam meningkatkan kepuasan pelayanan.

\section{Hipotesis penelitian kedua menyatakan bahwa:}

Hasil uji $\mathrm{t}$ dapat dilihat pada tabel 1 dari hasil regresi linier sederhana dengan penjelasan sebagai sebagai berikut:

$\mathrm{H}_{2}$ : Terdapat pengaruh sikap terhadap kepuasan pelayanan.

Berdasarkan hasil analisis regresi linier sederhana, variabel budaya perusahaan diperoleh nilai koefisien regresi sebesar 0.286 dan $t_{\text {hitung }}=1.677$ dengan tingkat signifikansi 0.006

Dengan menggunakan batas signifikansi 0.05, didapat $\mathrm{t}$ tabel sebesar 1.677. Ini berarti $\mathrm{t}$ hitung lebih besar dari $\mathrm{t}$ tabel, yaitu 2,864 lebih besar dari 1.677, berarti Ho ditolak dan Ha 
diterima.Dengan demikian maka hipotesis penelitian kedua $\left(\mathbf{H}_{2}\right)$ dapat diterima atau terbukti. Arah koefisien regresi positif berarti bahwa sikap memiliki pengaruh positif yang signifikan terhadap kepuasan pelayanan. Dengan kata lain dapat disimpulkan bahwa sikap penting dan berpengaruh dalam meningkatkan kepuasan pelayanan.

\section{Uji F (ANOVA)}

Uji $\mathrm{F}$ adalah untuk mengetahui apakah variabel hubungan penggunaan media sosial twitter Info Commuter Line PT KAI Indonesia, dan sikap penumpang di Stasiun Bojong Gede terhadap kepuasan pelayanan perjalanan kereta commuter line Jabodetabek. Hasil analisis uji $\mathrm{F}$ dapat dilihat pada tabel 2.

Tabel 2 Hasil Uji F ANOVA ${ }^{\mathrm{a}}$

\begin{tabular}{|ll|l|l|l|l|l|}
\hline \multicolumn{2}{|l|}{ Model } & $\begin{array}{l}\text { Sum of } \\
\text { Squares }\end{array}$ & & $\begin{array}{l}\text { Mean } \\
\text { Square }\end{array}$ & F & Sig. \\
\hline \multirow{2}{*}{1} & Regression & 364,658 & 2 & 182,329 & 296,909 &, $000^{\mathrm{b}}$ \\
& Residual & 28,862 & 47 &, 614 & & \\
& Total & 393,520 & 49 & & & \\
\hline
\end{tabular}

Sumber : Hasil pengolahan SPSS ver.21.00

\section{Hipotesis penelitian ketiga menyatakan bahwa:}

$\mathrm{H}_{3}$ : Terdapat pengaruh penggunaan media sosial Twitter Info Commuter Line PT KAI Indonesia, dan sikap penumpang di Stasiun Bojong Gede secara simultan terhadap kepuasan pelayanan perjalanan kereta commuter line Jabodetabek.

Berdasarkan tabel 2.di atas hasil pengujian hipotesis dengan menggunakan SPSS Ver. 21.00 dengan taraf signifikansi 5\% maka diperoleh $\mathrm{F}$ hitung sebesar 296,909 dan signifikansi 0.000. Sementara $F_{\text {tabel }}$ dilihat pada taraf signifikansi 5\% dengan df pembilang (k-2) dan df penyebut (n-k) maka diperoleh $\mathrm{F}_{\text {tabel }}$ yaitu $\mathrm{F}_{(2: 48)}=3.19$. Oleh karena $\mathrm{F}_{\text {hitung }}$ lebih besar dariF ${ }_{\text {tabel }}$, yaitu 296,909 lebih besar dari 3.19 dan signifikansi 0.000 lebih kecil dari 0.05, berarti Ho ditolak dan Ha diterima. Dengan demikian maka hipotesis penelitian ketiga $\left(\mathbf{H}_{3}\right)$ dapat diterima atau terbukti. Dengan demikian dapat disimpulkan bahwa penggunaan media sosial Twitter Info Commuter Line PT KAI Indonesia, dan sikap penumpang di Stasiun Bojong Gede dianggap penting dan berpengaruh signifikan dalam meningkatkan kepuasan pelayanan perjalanan kereta commuter line Jabodetabek.

\section{Uji $\mathbf{R}^{2}$ (Koefisien Determinasi)}

Analisis koefisien determinasi bertujuan untuk mengetahui seberapa besar kemampuan variabel-variabel independen (penggunaan media, dan sikap penumpang) secara bersama-sama dalam menjelaskan variabel dependen (kepuasan pelayanan). Dari hasil analisis dengan menggunakan program SPSS Ver. 21.00 dapat dilihat nilai $\mathrm{R}^{2}$ (Adjusted R Square) pada tabel 3 di bawah ini. 
Tabel 3 Hasil Koefisien Determinasi Model Summary ${ }^{\mathrm{b}}$

\begin{tabular}{|l|l|l|l|l|}
\hline $\begin{array}{l}\text { Mode } \\
1\end{array}$ & $\mathrm{R}$ & R Square & $\begin{array}{l}\text { Adjusted R } \\
\text { Square }\end{array}$ & $\begin{array}{l}\text { Std. Error of } \\
\text { the Estimate }\end{array}$ \\
\hline 1 &, $963^{\mathrm{a}}$ &, 927 &, 924 &, 784 \\
\hline
\end{tabular}

a. Predictors: (Constant), penggunaan media, sikap penumpang

Sumber : Hasil pengolahan SPSS ver.21.00

Dari tabel 3 di atas hasil korelasi r sebesar 0,963, hal ini memberi arti bahwa secara bersama-sama hubungan penggunaan media sosial twitter Info Commuter Line PT KAI Indonesia, dan sikap penumpang di Stasiun Bojong Gede dianggap penting dan berpengaruh signifikan dalam meningkatkan kepuasan pelayanan perjalanan kereta commuter line Jabodetabek mempunyai hubungan yang positif, searah, dan sangat tinggi. Jika nilai penggunaan media sosial, dan sikap penumpang naik, maka nilai kepuasan pelayanan juga akan naik. Nilai koefisien determinasi $\mathrm{R}^{2}$ (AdjustedR Square) sebesar 0,927 atau 92,7\%. Artinya kontribusi variabel-variabel bebas secara bersama-sama yaitu penggunaan media sosial, dan sikap penumpang terhadap kepuasan pelayanan adalah sebesar 92,7\% sedangkan sisanya sebesar 7,3\% dijelaskan oleh variabel lain yang tidak diteliti.

\section{PENUTUP}

Berdasarkan hasil penelitian dan pembahasan dapat disimpulkan bahwa penggunaan media sosial berpengaruh positif dan signifikan terhadap kepuasan pelayanan, artinya jika penggunaan media sosial meningkat maka kepuasan pelayanan akan meningkat. Dimensi jenis media, durasi dan frekuensi berhubungan kuat terhadap dimensi ekspektasi penumpang, persepsi kinerja dan kepuasan masa lalu.

Kemudian hasil penelitian berikutnya didapatkan kesimpulan bahwa sikap penumpang berpengaruh positif dan signifikan terhadap kepuasan pelayanan, artinya jika sikap penumpang senang maka kepuasan pelayanan akan meningkat. Dimensi kognitif, afektif, konatif dan percive value berhubungan kuat terhadap dimensi ekspektasi penumpang, persepsi kinerja dan kepuasan masa lalu.

Sementara dari sisi penggunaan media sosial, dan sikap penumpang secara bersamasama berpengaruh terhadap kepuasan pelayanan yaitu sebesar 92,7\%, sedangkan sisanya sebesar 7,3\% dijelaskan oleh variabel lain.

Berdasarkan kesimpulan di atas serta hasil yang dicapai dalam penelitian ini, maka penulis menyarankan beberapa hal penting sebagai bahan diskusi. Seperti untuk meningkatkan kepuasan pelayanan perjalanan kereta commuter line Jabodetabek maka PT KAI Indonesia perlu meningkatkan kualitas layanannya baik itu berupa sarana dan prasaranan maupun berupa manajemennya hingga menggunakan sarana media sosial lainnya selain twitter.

Berikutnya, PT KAI Indonesia commuter line merupakan solusi untuk mengurangi kepadatan dan kemacetan lalu lintas. Untuk itu PT KAI Indonesia commuter line perlu 
meningkatkan kualitas layanannya khususnya pada jam-jam sibuk seperti jam berangkat kerja dan jam pulang kerja. Hal ini dapat dilakukan dengan menambah frekuensi kedatangan dan keberangkatan kereta khususnya di daerah kantong pekerja.

Adapun untuk penelitian selanjutnya, dari temuan bahwa kepuasan pelayanan perjalanan kereta commuter line Jabodetabek masih ditentukan variabel lain yang tidak diteliti maka, disarankan untuk melakukan penelitian yang terkait dengan variabel seperti sumber daya manusia (SDM), manajemen, kebersihan, ketepatan waktu dan kenyamanan.

\section{REFERENSI}

Adisasmita, S. A. (2011). Jaringan Transportasi: Teori dan Analisis. Yogyakarta: Graha Ilmu.

Arikunto, S., (2006). Prosedur Penelitian Suatu Pendekatan Praktik. Jakarta: Rineka Cipta

Balaji, M. S., Khong, K. W., \& Chong, A. Y. L. (2016). Determinants of negative word-ofmouth communication using social networking sites. Information \& Management, 53(4), 528-540.

Baran, S. J., \& Davis, D. K. (2011). Mass communication theory: Foundations, ferment, and future. Cengage Learning.

Boone, L., \& Kurtz, D. (2004). Contemporary Marketing.

Cronin Jr, J. J., Brady, M. K., \& Hult, G. T. M. (2000). Assessing the effects of quality, value, and customer satisfaction on consumer behavioral intentions in service environments. Journal of retailing, 76(2), 193-218.

Dawar, N., \& Parker, P. (1994). Marketing universals: Consumers' use of brand name, price, physical appearance, and retailer reputation as signals of product quality. The Journal of Marketing, 81-95.

Dhaha, I. S. Y., \& Igale, A. B. (2013). Facebook usage among Somali youth: A test of uses and gratifications approach. International Journal of Humanities and Social Science, 3(3), 299-313.

Faed, A., Hussain, O. K., \& Chang, E. (2014). A methodology to map customer complaints and measure customer satisfaction and loyalty. Service Oriented Computing and Applications, 8(1), 33-53.

Foster-Fishman, P. G., Berkowitz, S. L., Lounsbury, D. W., Jacobson, S., \& Allen, N. A. (2001). Building collaborative capacity in community coalitions: A review and integrative framework. American journal of community psychology, 29(2), 241-261.

Grant, B. M., \& Giddings, L. S. (2002). Making sense of methodologies: A paradigm framework for the novice researcher. Contemporary nurse, 13(1), 10-28.

Hardiyansyah. (2011). Kualitas Pelayanan Publik: Konsep, Dimensi, Indikator dan Implementasinya. Yogyakarta: Gava Media.

Hidayat, R. (2009). Pengaruh kualitas layanan, kualitas produk dan nilai nasabah terhadap kepuasan dan loyalitas nasabah Bank Mandiri. Jurnal Manajemen dan kewirausahaan, 11(1), pp-59.

Jayanti, N. Y., \& Hardjo, R. (2013). Kualitas Pelayanan KRL Commuter Line Rute JakartaBogor Berdasarkan Persepsi Mahasiswa Universitas Indonesia. Skripsi. Depok. Universitas Indonesia. 
Kania, D., \& Agatha, N. (2012). Online Consumers and The Application of Uses and Gratification Theory Case Study: The Kaskus Website. Journal Communication Spectrum, 1(2).

Lam, S. Y., Shankar, V., Erramilli, M. K., \& Murthy, B. (2004). Customer value, satisfaction, loyalty, and switching costs: An illustration from a business-to-business service context. Journal of the academy of marketing science, 32(3), 293-311.

Myers, R. E., \& Fouts, J. T. (1992). A cluster analysis of high school science classroom environments and attitude toward science. Journal of Research in Science Teaching, 29(9), 929-937.

Schwartz, S. H. (2012). An overview of the Schwartz theory of basic values. Online readings in Psychology and Culture, 2(1), 11.

Seol, S., Lee, H., Yu, J., \& Zo, H. (2016). Continuance usage of corporate SNS pages: A communicative ecology perspective. Information \& Management, 53(6), 740-751.

Shader, M. (2001). Risk factors for delinquency: An overview. US Department of Justice, Office of Justice Programs, Office of Juvenile Justice and Delinquency Prevention.

Tjiptono, F. (2012). Service Management Mewujudkan Layanan Prima. Yogyakarta: CV. Andi Offset.

Treem, J. W., \& Leonardi, P. M. (2013). Social media use in organizations: Exploring the affordances of visibility, editability, persistence, and association. Annuals of the International Communication Association, 36(1), 143-189.

Wasistiono, S. (2011). Manajemen Pemerintahan Daerah. Bandung: Alqo Print. 